\title{
Zooplankton growth, diet and reproductive success compared in simultaneous diatom- and flagellate- microzooplankton-dominated plankton blooms
}

\author{
Jens C. Nejstgaard ${ }^{1, *}$, Bent Hansen Hygum ${ }^{2}$, Lars-Johan Naustvoll ${ }^{3}$, Ulf Båmstedt ${ }^{1}$ \\ ${ }^{1}$ Department of Fisheries and Marine Biology, University of Bergen, Bergen High Technology Center, PO Box 7800, \\ 5020 Bergen, Norway \\ ${ }^{2}$ Institute of Life Sciences and Chemistry, Roskilde University, PO Box 260, 4000 Roskilde, Denmark \\ ${ }^{3}$ Flødevigen Research Station, Institute of Marine Research, 4817 His, Norway
}

\begin{abstract}
Development of mesozooplankton biomass, feeding activity and reproductive success of the copepod Calanus helgolandicus were compared in blooms of natural plankton in 7 mesocosms on the west coast of Norway between 28 August and 28 September 1996. Nutrient content and turbulence in enclosures of $27 \mathrm{~m}^{3}$ natural sea water were manipulated in situ in order to generate blooms dominated by diatoms and flagellate-microzooplankton respectively. The diatom-dominated mesocosms reached the highest algal biomasses. Calanus helgolandicus generally preferred non-diatom food, such as ciliates and metazoans, and showed similar ingestion rates in both systems. The female body-carbon-specific nauplii production was highest $\left(10.6 \% \mathrm{~d}^{-1}\right)$ during a flagellate-microzooplankton bloom, before it dropped to ca $1.7 \% \mathrm{~d}^{-1}$ during a bloom of Dictyocha speculum. In the diatomdominated water it dropped to as low as $0.1 \%$, and was always $<5.2 \% \mathrm{~d}^{-1}$. The total standing stock of calanoid copepods increased about 2.6 times more in the flagellate-microzooplankton-dominated mesocosms. The drop in reproductive success in diatom-dominated water was recorded when feeding rates were high, and ciliates and other prey made up a substantial part of the diet. This suggests that either all prey, including the ciliates, were of poor quality and/or that inhibitory components may be an important factor during diatom blooms, even when significant amounts of alternative prey are available. Our results also suggest that blooms of the silicoflagellate $D$. speculum may affect copepod reproduction negatively in the sea.
\end{abstract}

KEY WORDS: Calanus $\cdot$ Skeletonema costatum $\cdot$ Dictyocha $\cdot$ Microzooplankton $\cdot$ Diatom $\cdot$ Selective grazing $\cdot$ Reproduction · Egg hatching

Resale or republication not permitted without written consent of the publisher

\section{INTRODUCTION}

There is a consensus that the nutritional composition of prey is one of the key factors determining zooplankton reproductive output (e.g. Jónasdóttir \& Kiørboe 1996, Jónasdóttir et al. 1998, Kleppel et al. 1998, Laabir et al. 1999). It is also well known that copepods ingest diatoms and may produce eggs at high rates during

*E-mail: jens.nejstgaard@ifm.uib.no diatom blooms (e.g. Hygum et al. 2000, and references therein). However, an increasing number of reports question the role of diatoms as a key factor for reproductive success in copepods. Feeding deterrents (Malej \& Harris 1993, Shaw et al. 1995) and substances reducing hatching success and inhibiting embryonal development have been shown to be present in common diatoms such as Skeletonema costatum and Chaetoceros spp. (e.g. Ban et al. 1997, Ianora et al. 1999a, Miralto et al. 1999, Laabir et al. 2001, and references therein). 
In contrast to diatoms, microzooplankton such as ciliates are often a preferred prey for omnivorous copepods such as Calanus spp. (e.g. Stoecker \& Capuzzo 1990, Kleppel 1993, Nejstgaard et al. 1997, Nejstgaard et al. 2001, this issue, and references therein). Some microzooplankton may also show a more balanced nutritional composition than their algal prey (Kleppel 1993, Kleppel \& Burkart 1995, Klein Breteler et al. 1999) and may support high reproduction of copepods in the field (Kleppel et al. 1991, Ohman \& Runge 1994). However, suboptimally sized prey, such as flagellates, may also have favourable nutritional composition (Støttrup \& Jensen 1990, Pond \& Harris 1996), and may thus support high production of viable eggs in copepods, at least during blooms (Nejstgaard et al. 1997, Båmstedt et al. 1999).

A number of laboratory studies have shown clear effects of nutrient deficiencies on copepod reproduction when feeding on a limited number of food items (e.g. Jónasdóttir 1994, Kleppel et al. 1998). This may not necessarily be found in natural plankton due to the diversity of available prey (Roman 1984, Schmidt \& Jónasdóttir 1997, Schmidt et al. 1998), and nutritional enrichment through the food chain (cf. Kleppel \& Burkart 1995, Klein Breteler et al. 1999).

Field studies aimed at quantifying the dietary effect of diatoms on copepod reproductive success are still limited (see discussions in Ban et al. 1997, 2000, Miralto et al. 1999). They also suffer from methodological problems related to time-scale and variable feeding and reproductive history of the copepods. The field studies generally compare the in situ phytoplankton community (and in some cases faecal pellet content), with egg production and hatching success of field-collected animals within a period of 24 h (e.g. Jónasdóttir et al. 1995, Laabir et al. 1995, Pond et al. 1996, Laabir et al. 1998). The comparison of wild individuals sampled at discrete occasions has a number of strong limitations. Differences in hatching success may not be related to food conditions at all, but e.g. gonadal development (Niehoff 1996), remating success (Parrish \& Wilson 1978), sperm quality (Ianora et al. 1999b), pollutants (Hook \& Fisher 2001) and/or variable feeding history. Pellet production is a result of feeding activity within the last hour (e.g. Kiørboe \& Tiselius 1987), while egg production is a result of feeding history over the preceding days (Hirche et al. 1997), or even weeks (Båmstedt et al. 1999). Likewise, a full negative effect of possible deleterious substances from the diatoms may be visible only after days or weeks of exposure (Laabir et al. 1999). Thus, the observed large variability, and the inability to establish direct correlations between in situ prey items and copepod reproductive success in field studies may not be due to lack of a relation per se, but rather to a methodological problem.
Here we report on a long duration comparison of selective feeding and reproductive success in Calanus helgolandicus fed natural plankton dominated either by diatoms or flagellate/microzooplankton. We also compare the net increase in different mesozooplankton groups in 7 mesocosms, 4 with and 3 without significant diatom blooms.

\section{MATERIALS AND METHODS}

Mesocosms and experimental material. A mesocosm experiment was conducted at the Marine Biological Field Station of the University of Bergen, Norway, between 28 August and 28 September 1996. Eight $27 \mathrm{~m}^{3}$ (2 m diameter, $9.25 \mathrm{~m}$ deep) transparent $(90 \%$ penetration PAR) polyethylene enclosures were filled in situ by pumping unfiltered water from $5 \mathrm{~m}$ depth (salinity ca $31.0 \pm 0.1 \mathrm{psu}$ ). In order to achieve stratification of the water column, the mesocosms were slowly topped up with ca $0.6 \mathrm{~m}^{3}$ freshwater. The upper $4.5 \mathrm{~m}$ of the water column was mixed and kept homogenous with air-lifts throughout the experiment (salinity ca $29.8 \pm 0.3 \mathrm{psu}$ ). On 2 September, nutrients were added to the upper layers corresponding to final concentrations of $1.5 \mu \mathrm{mol} \mathrm{l^{-1 }}$ nitrate and $0.1 \mu \mathrm{mol} \mathrm{l} \mathrm{l}^{-1}$ phosphate. Silicate was also added to the upper layer in 4 of the mesocosms, to a final concentration of $1.5 \mu \mathrm{mol} \mathrm{l^{-1 }}$. Different turbulence regimes were created by vertically moving perspex grids, but this had little effect on plankton development (Svensen et al. 2001). Abbreviations and treatments for the different mesocosms are given in Table 1 (note that 1 enclosure collapsed and was omitted from the experiment). The water in the mesocosms was not renewed but at 12 and 19 September ca $0.7 \mathrm{~m}^{3} 30 \mu \mathrm{m}$ screened sea water was added to each of the mesocosms to replace water removed by sampling. For further description of the mesocosm experimental design see Svensen et al. (2001); a general description of the mesocosm facility is available at: www.ifm.uib.no/LSF/inst2.html.

Mesozooplankton was sampled at the start of the mesocosm experiment by filtering $4 \mathrm{~m}^{3}$ water through a $90 \mu \mathrm{m}$ net at 3 separate occasions during the filling

Table 1. Design of mesocosm experiments

\begin{tabular}{|lcc|}
\hline Mesocom & Nutrient added & Turbulence \\
\hline L1, L2 & N, P & Low \\
H1 ${ }^{\text {a }}$ & N, P & High \\
SL1, SL2 & N,P, S & Low \\
SH1, SH2 & N, P, S & High \\
anclosure H2 collapsed and was omitted from the experi- \\
ment
\end{tabular}


procedure. At the termination of the experiment (28 September) the water from each of the 7 mesocosms was emptied through the $90 \mu \mathrm{m}$ net to collect the mesozooplankton. Samples were fixed in $4 \%$ buffered formaldehyde.

We focused on 2 of the mesocosms: L1 and SH1. The former was expected to give a flagellate-microzooplankton-dominated bloom and the latter to give a diatom-dominated bloom. Water for analysis of chl $a$, phytoplankton, and microzooplankton abundance in the L1 and SH1 mesocosms was sampled on 9 occasions between 8 and 24 September at $2 \mathrm{~m}$ depth. Copepod grazing and egg production experiments were conducted with water from these 2 bags. Females of Calanus helgolandicus for the egg production and grazing experiments were collected from the surface water $(0$ to $20 \mathrm{~m}$ ) of the nearby Raunefjorden, using a $1.2 \mathrm{~m}$ diameter, $700 \mu \mathrm{m}$ mesh net with a $14 \mathrm{l}$ nonfiltering codend. Actively swimming undamaged copepods were sorted out using wide-mouth pipettes at in situ temperature shortly after collection. The same set of females was used for egg production throughout the period, and an additional set was started $1 \mathrm{wk}$ before termination of the experiment.

Grazing experiments. Using water from each of the mesocosms, L1 and SH1, 2 sets of zooplankton grazing experiments were performed; the first were run during the initial bloom phases in the respective mesocosms (Expts L1a and SH1a), and the second during the height of the respective blooms (Expts L1b and SH1b, see Fig. 1).

In each set of experiments we quantified selective grazing both by the microzooplankton community and by female Calanus helgolandicus, by combining sea water dilution experiments (Landry 1993) and copepod food removal bottle incubation experiments (e.g. Omori \& Ikeda 1984, Båmstedt et al. 2000), according to the method presented in Nejstgaard et al. (2001). No nutrients were added to the bottles in order to avoid unnecessary changes in the experimental nutrient conditions (e.g. Landry 1993). However, due to nutrient additions to the mesocosms, levels were not limiting (see Nejstgaard et al. 2001 for further details). Copepods were acclimated in the experimental water for $24 \mathrm{~h}$ prior to the incubations. All bottles (2.3 1 polycarbonate) were incubated in situ outside the mesocosms (22 to $25 \mathrm{~h}$ ), hanging horizontally in strings from a floating ring at $1 \mathrm{~m}$ depth. This creates a gentle irregular tipping movement to prevent sedimentation in the flasks. For each dilution in the dilution series $(10,30$ and $100 \%$ undiluted water) 3 bottles were sampled at the start and the termination of the experiment. This provided both microzooplankton grazing rates and the $100 \%$ undiluted water bottles also served as blanks for the copepod experiment. For determination of cope- pod grazing rates, 4 bottles containing copepods (10 to 12 bottle $^{-1}$ ) were sampled at the termination of the experiment.

Sampling was done after gently turning the completely full incubation bottles upside down 20 times, by gentle siphoning while slowly stirring with a hose fitted with a $200 \mu \mathrm{m}$ mesh to exclude copepods. This was done to ensure even sampling with a minimum of disturbance of delicate microzooplankton. Thereafter copepods were screened on $200 \mu \mathrm{m}$ submerged net and were immediately counted and examined for stage and viability under a dissecting microscope before being fixed in $4 \%$ hexamine buffered formaldehyde. Samples were taken for chl a and for counting of phytoplankton and microzooplankton; the remaining water was screened for particles $>40 \mu \mathrm{m}$, fixed in formaldehyde, and later enumerated for less abundant, larger sized microzooplankton, eggs and faecal pellets. The method for grazing rate calculation is summarised below and a discussion of the method is given in Nejstgaard et al. (2001).

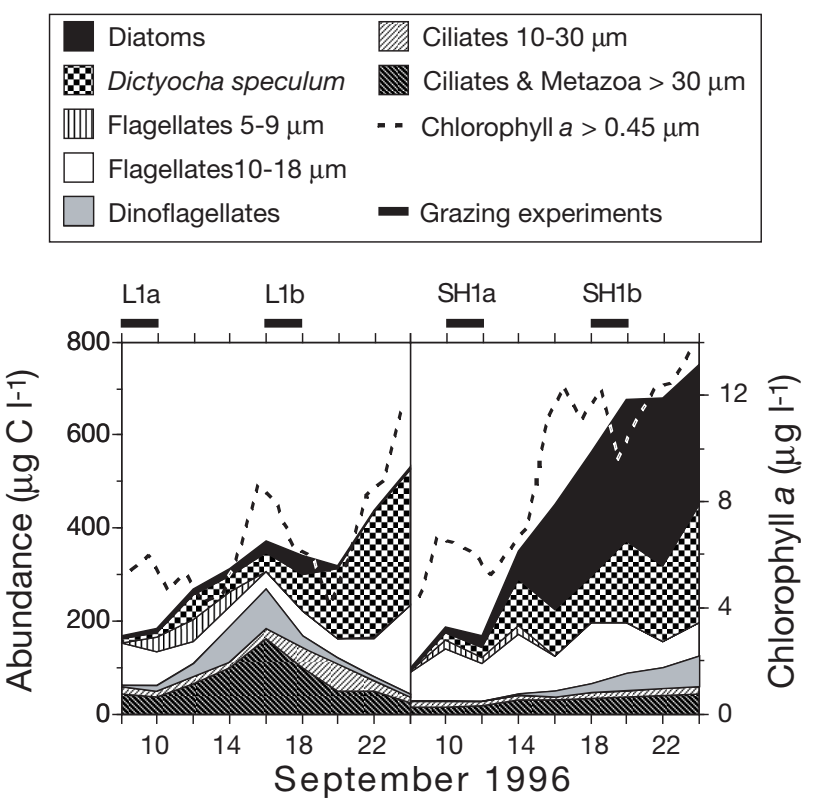

Fig. 1. Development of algae, microzooplankton and chl $a$ in the mesocosms L1 and SH1 between 8 and 24 September 1996. Ciliates are mainly aloricate species. Ciliates \& Metazoa both $>30 \mu \mathrm{m}$ ESD (equivalent spherical diameter) are dominated by ciliates. Dinoflagellates, other flagellates and ciliates include both aplastidic and plastidic species. Flagellates 5 to 9 $\mu \mathrm{m}$ include Emiliania huxleyi. Flagellates 10 to $18 \mu \mathrm{m}$ are mainly unidentified 12 to $15 \mu \mathrm{m}$ species, but also include Ebria tripartita. Dictyocha speculum was generally naked, the exoskeleton-bearing form was only detected in L1 $(<9 \mu \mathrm{gC}$ $\mathrm{l}^{-1}$ ). The times of the microzooplankton and copepod grazing experiments (L1a, L1b, SH1a, SH1b) are indicated at the top of the figures, including the overnight copepod acclimation period prior to the incubations 
Egg production experiments. Egg and pellet production experiments were conducted in a cold room at in situ temperature $\left(\mathrm{ca} 10^{\circ} \mathrm{C}\right)$ with a light:dark cycle of 14:10 h, using indirect, dimmed light. Female Calanus helgolandicus were kept singly in $450 \mathrm{ml}$ perspex chambers with $500 \mu \mathrm{m}$ mesh false bottoms, to prevent egg and pellet re-ingestion. Between 5 and 8 September, all females were fed surplus concentrations $\left(900 \mathrm{\mu gC} \mathrm{l}^{-1}\right)$ of Rhodomonas baltica, a well-studied food alga for cultures of copepods (Støttrup \& Jensen 1990, Nejstgaard et al. 1995, Båmstedt et al. 1999). Females that had not spawned during this acclimation period were considered pre- or post-reproductive and were omitted from further experimentation. On 8 September the acclimated females were randomly distributed into 3 series ( $\mathrm{n}=30$ in each series), and kept either in water from the L1 or SH1 mesocosms, or on $R$. baltica as a reference series, throughout the mesocosm experiment (series 'L1', 'SH1' and 'Rhodomonas baltica'). In order to investigate whether prolonged handling of the females had a significant effect on the egg and pellet production we introduced 2 new series of females ( $\mathrm{n}=12$ in each series), acclimated like the first series and then kept in water from the L1 or SH1 mesocosms from 19 September (series 'New L1' and 'New SH1'). Females were controlled for viability and transferred to new food suspensions daily. Care was taken not to disrupt eggs and faecal pellets during sampling. Eggs and faecal pellets were gently collected by reverse filtration ( $30 \mu \mathrm{m}$ mesh size), washed into counting chambers, counted under a dissecting microscope and backwashed into beakers that were gently aerated. After incubation for 50 to $55 \mathrm{~h}$, eggs and hatched nauplii were re-collected for enumeration in the same way to determine hatching success. A few females that were either accidentally killed during the daily transfer process or which died shortly after initiation of the series were omitted from further analysis.

Analysis of the samples and calculation of biomasses. Replicate chl a samples were filtered onto $25 \mathrm{~mm}$ diameter and $0.45 \mu \mathrm{m}$ pore size cellulose nitrate filters (pressure $<6 \mathrm{~mm} \mathrm{Hg}$ ). Samples were frozen $\left(-22^{\circ} \mathrm{C}\right)$ until extraction overnight in $90 \%$ acetone, and were measured on a Turner Designs Model 10-AU Fluorometer according to the method given by Welschmeyer (1994). Phytoplankton samples were preserved with a glutardialdehyde-lugol mix (35\% final v/v) (Rousseau et al. 1990), settled in 2 or $50 \mathrm{ml}$ sediment chambers and counted and sized at $400 \times$ magnification. Microzooplankton samples were fixed in acid Lugol's solution (final concentration $1 \%$ ), settled in $50 \mathrm{ml}$ sediment chambers, counted at $200 \times$ and sized at $400 \times$ magnification. For counting and sizing of phytoplankton and microzooplankton a Wild M40 inverted microscope equipped with a calibrated ocular micro-meter was used. Cell volume was calculated using simple geometrical formulae (Edler 1979, Ohman \& Snyder 1991). Cell volume was converted into $C$ according to the equations by Menden-Deuer \& Lessard (2000): $\log \mathrm{pgC} \mathrm{cell}^{-1}=\log \mathrm{a}+\mathrm{b} \log V$, where $V$ is cell volume $\left(\mu \mathrm{m}^{3}\right)$, and $\log a=-0.541$ and $b=0.811$ for diatoms, and $\log a=-0.665$ and $b=0.939$ for all other protist plankton except aloricate ciliates. Aloricate ciliate cell volume was converted into carbon by a factor of $0.19 \mathrm{pgC}$ $\mu \mathrm{m}^{-3}$ (Putt \& Stoecker 1989). The $40 \mu \mathrm{m}$ mesh net samples for larger microzooplankton were examined under a dissecting microscope (Wild M10). Copepod egg and faecal pellet volume was determined on a Macintosh Power computer using an image analysis system (Photometrics sensys CCD camera system: Roper Scientific, Trenton, NJ, USA; IPLab: Scanalytics, Billerica, MA, USA). Live eggs were individually sorted with pipettes, rinsed in pre-filtered sea water $(0.2 \mu \mathrm{m})$, and then placed on pre-combusted GF/C filters; the number of eggs was then carefully re-examined under a stereomicroscope. Filters that were treated identically, but excluding eggs, were used for correction of background levels of $\mathrm{C}$ in the experimental water. The samples were dried at $60^{\circ} \mathrm{C}$ overnight and stored at $-18^{\circ} \mathrm{C}$ for later measurement on an IRGA infrared gas analyser ADC 225 MK3 (Analytical Development Company, Hoddeson, UK). Carbon content was determined for 30 to 40 eggs, from which a mean carbon value was calculated. Carbon content of late stages of Calanus helgolandicus was determined for single specimens following the procedure described above. For all other zooplankton, abundance was converted into carbon by species- and stage-specific values obtained from the literature (Båmstedt 1986, Blom et al. 1989, Båmstedt et al. 1990, Widdows 1991, Karlson \& Båmstedt 1994), using the conversion factor of $0.547 \mathrm{C}$ :dry wt $(\mu \mathrm{g})$ for copepods from high latitudes (Båmstedt 1986). Egg numbers were converted into carbon by a factor of $0.387 \mu \mathrm{gC} \mathrm{egg}^{-1}$, determined in this study (see 'Results').

Calculations of growth and grazing rates. Algal growth rates, microzooplankton grazing coefficients and daily grazing impact were calculated according to Landry (1993). Microzooplankton grazer abundance was normalised to natural density in terms of total microzooplankton body carbon in the respective grazing bottles (cf. Landry 1993). Due to the small number of samples per experiment $(n=9)$ the microzooplankton grazing data were not tested for nonlinearity, and they may therefore be considered as minimum estimates (cf. Gallegos 1989).

Copepod clearance and ingestion rates were calculated according to the equations by Frost (1972), but corrected for reduced microzooplankton grazing due to predation by the copepods $(k)$, according to the formula given by Nejstgaard et al. (2001): 


$$
g_{\mathrm{corr}, p}=g_{\mathrm{cop}, p}+k_{p}
$$

where $g_{\text {corr, } p}$ is the corrected copepod grazing coefficient for prey type $p\left(\mathrm{~d}^{-1}\right), g_{\text {cop }, p}$ is the uncorrected copepod grazing coefficient for prey type $p$ according to Frost (1972), and $k_{p}$ is the correction for loss of microzooplankton grazing on prey type $p$ in the copepod bottle. $k_{p}$ is calculated according to Eq. (2):

$$
\begin{gathered}
k_{p}=g_{\text {mic }, p}\left(\frac{\bar{C}-\bar{C}^{*}}{\bar{C}}\right) \\
\bar{C}=\left(c_{t}-c_{0}\right) / \ln \left(c_{t} / c_{0}\right) \\
\bar{C}^{*}=\left(c_{t}^{*}-c_{0}\right) / \ln \left(c_{t}^{*} / c_{0}\right)
\end{gathered}
$$

where $g_{\text {mic }, p}$ is the microzooplankton grazing coefficient for prey type $p\left(\mathrm{~d}^{-1}\right.$, obtained from the simultaneously performed dilution experiments), $\bar{C}$ and $\bar{C}^{*}$ is the calculated average concentration of all microzooplankton $\left(\mu \mathrm{gC}^{-1}\right)$ in the blank and copepod bottles respectively, $C_{0}$ is the measured concentration of all microzooplankton at the start of the incubation, while $c_{t}$ and $c_{t}{ }^{*}$ are the measured concentrations of all microzooplankton at the end of the incubation in the blank (average for all blanks) and the copepod bottle respectively.

Feeding preference index. In order to test whether the copepods were feeding selectively, prey preference was calculated as Manly's (1974) index for variable prey populations, normalized for copepod concentration as described in Nejstgaard et al. (1997).

Faecal to ingestion conversion. Copepod faecal pellet production rates were converted into ingestion rates according to Eq. (5) for copepods fed natural plankton (mesocosm water), and Eq. (6) for copepods fed cultures of Rhodomonas baltica, respectively:

$$
\begin{aligned}
& y=0.35 x+4.63 \\
& y=0.41 x+1.57
\end{aligned}
$$

where $x$ is the faecal pellet production rate (pellets copepod $^{-1} \mathrm{~d}^{-1}$ ), and $y$ is the copepod carbon ingestion rate $\left(\mu \mathrm{gC}\right.$ copepod $\left.^{-1} \mathrm{~d}^{-1}\right)$. Eq. (5) is based on 33 bottle incubations with Calanus finmarchicus and C. helgolandicus stage CVs and adult females grazing natural plankton (Nejstgaard et al. 2001), including experiments presented here. Eq. (6) is derived from 45 bottle incubations with $C$. finmarchicus stage CVs and adult females grazing on laboratory cultures of $R$. baltica (Båmstedt et al. 1999).

Statistical analysis. Data were tested for normality, before running ANOVA and post hoc tests. Multiple comparisons among groups were tested using either Scheffé's multiple contrasts (Zar 1996, p. 222-225), or if $n>6$, the post hoc test by Games \& Howell (1976). These tests were chosen due to their general robustness and to reduce type I errors.

\section{RESULTS}

\section{Mesocosm development}

In the silicate-fertilised mesocosm SH1, a diatomand Dictyocha speculum-dominated phytoplankton bloom developed that reached close to $800 \mathrm{\mu gC}^{-1}$ by 24 September (Fig. 1). In contrast, the non-silicate mesocosm L1 developed 2 successive phytoplankton increases: first a peak dominated by microzooplankton and dinoflagellates and later a bloom almost entirely consisting of naked forms of the silicoflagellate $D$. speculum and flagellates $<10 \mu \mathrm{m}$, including Emiliania huxleyi (Fig. 1). The blooms in L1 reached ca 400 and $500 \mu \mathrm{gC} \mathrm{l}^{-1}$ respectively (Fig. 1). The chl a concentration was relatively high compared to the initial cell counts in both mesocosms (Fig. 1). This may be due to algae $<5 \mu \mathrm{m}$, as these were not counted. In accordance with our data (Fig. 1), a summary of the unpublished results of J. K. Egge and U. Tillmann (Table 2) shows that Si-fertilised mesocosms had higher average pri-

\begin{tabular}{|c|c|c|c|c|c|c|c|c|c|}
\hline Mesocosm & $\begin{array}{l}\text { Primary } \\
\text { production }\end{array}$ & $\begin{array}{c}\text { Chl a } \\
>0.45 \mu \mathrm{m}\end{array}$ & POC & PON & $\mathrm{P} / \mathrm{N}$ & Diatoms & $\begin{array}{c}\text { Other } \\
\text { phyto- } \\
\text { plankton }\end{array}$ & $\begin{array}{l}\text { Microzoo- } \\
\text { plankton }\end{array}$ & $\begin{array}{c}\text { Total } \\
\text { cell } \\
\text { count C }\end{array}$ \\
\hline L1 & 20 & 6.9 & 982 & 154 & 6.4 & 11 & 355 & 155 & 521 \\
\hline L2 & 16 & 4.0 & 755 & 123 & 6.1 & & & & \\
\hline H1 & 23 & 7.8 & 892 & 139 & 6.4 & 6 & 399 & 75 & 481 \\
\hline SL1 & 23 & 11.3 & 1303 & 176 & 7.4 & 336 & 260 & 46 & 642 \\
\hline SL2 & 25 & 8.4 & 1276 & 166 & 7.7 & & & & \\
\hline SH1 & 25 & 8.4 & 1130 & 145 & 7.8 & 453 & 289 & 53 & 796 \\
\hline SH2 & 26 & 8.9 & 1216 & 159 & 7.6 & & & & \\
\hline
\end{tabular}
mary production, chl $a$, diatom and total protist con-

Table 2. Average primary production $\left({ }^{14} \mathrm{C}_{\mathrm{gg} \mathrm{C}} \mathrm{l}^{-1} \mathrm{~d}^{-1}\right)$, chl a $\mu \mathrm{g} \mathrm{l} \mathrm{l}^{-1}$, particulate organic $\mathrm{C}$ (POC) and N (PON), POC/PON quota

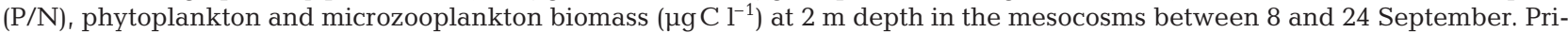
mary production, chl $a$ and phytoplankton data from Jorun K. Egge (unpubl.) and microzooplankton from Urban Tillmann (unpubl.). Other phytoplankton was dominated by flagellates and microzooplankton was mainly ciliates 
centrations between 8 and 24 September, compared to the non-Si mesocosms. However, the microzooplankton concentration was on average $2.3 \times$ higher in the non-Si mesocosms, compared to the Si-fertilised ones (Table 2, Fig. 1). The diatoms were dominated by Skeletonema costatum and Amphiprora sp., while the microzooplankton was dominated by naked ciliates such as Strombidium spp. and Strombilidium spp., and to a lesser degree by the dinoflagellate Protoperidinium bipes.

\section{Grazing experiments}

The microzooplankton community showed relatively high grazing rates, corresponding to a removal of 30 to $63 \%$ of the total chl $a$, and as much as 63 to $74 \%$ of the different phytoplankton standing stocks per day (Table 3). This also led to substantial microzooplankton corrections (cf. Eq. 2), resulting in significantly positive copepod grazing rates, despite negative uncorrected rates (Tables 4 \& 5).

The preferred prey for Calanus helgolandicus was larger items, such as metazoans and ciliates $>30 \mu \mathrm{m}$ equivalent spherical diameter (ESD, Table 4). In contrast, flagellates $<10 \mu \mathrm{m}$ were never preferred food. The larger flagellates were significantly $(\mathrm{p}<0.05)$ grazed in L1a, while they were significantly $(p<0.01)$ avoided in all other experiments when they were dom- inated by Dictyocha speculum (Table 4). Although diatoms made up the bulk of the copepod food during the bloom of diatoms (Expt SH1b, Table 4) it was generally not a selected food item (prey preference $<11.1$, Table 4). Ciliates $>30 \mu \mathrm{m}$ and metazoa always made up 2.5 to $6.8 \times$ higher proportion of the diet than of the available prey concentration, with the highest proportions during the highest diatom concentrations (Expts SH1a,b, Table 4).

\section{Calanus fecundity and faecal pellet production experiments}

The production rates of eggs and faecal pellets, and hatching success are presented in Fig. 2. However, females with a constant diet of Rhodomonas baltica showed that both pellet and egg production rates were significantly linearly correlated to the body size (Fig. 3). Thus, in order to reduce the bias of different average body sizes in the comparison between the treatments we also computed body-carbon-specific ingestion and reproduction rates (Fig. 4). In contrast to body size, average egg diameter $(171 \pm 9 \mu \mathrm{m}, \pm \mathrm{SD}$, $\mathrm{n}=959)$ and $\mathrm{C}$ content per egg $(0.387 \pm 0.058 \mu \mathrm{g}, \pm \mathrm{SD}$, $\mathrm{n}=30$ ) did not vary significantly with treatment or female size ( $\mathrm{p}>0.05$, not shown).

The fecundity of Calanus helgolandicus generally differed much more between the treatments than did pellet

Table 3. Microzooplankton grazing experiments. Specific algal growth rate $\left(\mu_{i} \mathrm{~d}^{-1}\right)$, microzooplankton grazing coefficient $\left(g, \mathrm{~d}^{-1}\right)$, and grazing impact as percentage of average standing stock removed $\mathrm{d}^{-1}$. Mean $\pm \mathrm{SE} .{ }^{*} \mathrm{p}<0.05,{ }^{* *} \mathrm{p}<0.01$, and ${ }^{* * *} \mathrm{p}<0.001$ for $\mu$ or $g=0, \mathrm{n}=9$. Prey types are given with equivalent spherical diameter size ranges $(\mu \mathrm{m})$. Dinoflagellates are only plastidic species. Only significant $g$-values $(\mathrm{p}<0.05)$ were used for corrections of copepod grazing rates

\begin{tabular}{|c|c|c|c|c|c|}
\hline Prey type & Grazing experiment & $\mathrm{r}^{2}$ & $\mu$ & $g$ & Grazing impact \\
\hline \multirow[t]{4}{*}{ Chl a (>0.45) } & L1a & 0.73 & $0.10 \pm 0.04$ & $0.34 \pm 0.07^{* *}$ & 29 \\
\hline & L1b & 0.75 & $0.58 \pm 0.07^{* * *}$ & $0.55 \pm 0.11^{* *}$ & 42 \\
\hline & SH1a & 0.80 & $0.15 \pm 0.05^{*}$ & $0.47 \pm 0.08^{* * *}$ & 37 \\
\hline & SH1b & 0.90 & $0.79 \pm 0.07^{* * *}$ & $0.98 \pm 0.12^{* * *}$ & 63 \\
\hline \multirow[t]{4}{*}{ Diatoms (8-15) } & L1a & 0.71 & $1.10 \pm 0.12^{* * *}$ & $0.84 \pm 0.22^{* *}$ & 57 \\
\hline & L1b & 0.01 & $-0.58 \pm 0.06^{* * *}$ & $-0.03 \pm 0.12$ & \\
\hline & SH1a & 0.99 & $1.23 \pm 0.03^{* * *}$ & $1.12 \pm 0.06^{* * *}$ & 67 \\
\hline & SH1b & 0.94 & $0.57 \pm 0.03^{* * *}$ & $0.47 \pm 0.05^{* * *}$ & 37 \\
\hline \multirow[t]{4}{*}{ Flagellates (4-9) } & L1a & 0.51 & $0.10 \pm 0.04$ & $0.20 \pm 0.08^{*}$ & 18 \\
\hline & L1b & 0.72 & $0.43 \pm 0.04^{* * *}$ & $0.30 \pm 0.08^{* *}$ & 26 \\
\hline & SH1a & 0.98 & $0.86 \pm 0.03^{* * *}$ & $0.84 \pm 0.05^{* * *}$ & 57 \\
\hline & SH1b & 0.45 & $0.05 \pm 0.08$ & $0.34 \pm 0.15^{*}$ & 29 \\
\hline \multirow[t]{4}{*}{ Flagellates (10-18) } & L1a & 0.01 & $0.28 \pm 0.17$ & $0.06 \pm 0.31$ & 6 \\
\hline & L1b & 0.31 & $0.68 \pm 0.10^{* * *}$ & $0.31 \pm 0.19$ & 26 \\
\hline & SH1a & 0.95 & $1.30 \pm 0.07^{* * *}$ & $1.34 \pm 0.13^{* * *}$ & 74 \\
\hline & SH1b & 0.00 & $0.00 \pm 0.07$ & $0.02 \pm 0.14$ & 2 \\
\hline \multirow[t]{4}{*}{ Dinoflagellates (12-20) } & L1a & 0.03 & $0.36 \pm 0.09^{* *}$ & $0.08 \pm 0.17$ & 7 \\
\hline & L1b & 0.81 & $0.34 \pm 0.07^{* *}$ & $0.64 \pm 0.13^{* *}$ & 47 \\
\hline & SH1a & 0.91 & $1.44 \pm 0.09^{* * *}$ & $1.24 \pm 0.16^{* * *}$ & 71 \\
\hline & SH1b & 0.50 & $0.75 \pm 0.16^{* *}$ & $0.72 \pm 0.29^{*}$ & 51 \\
\hline
\end{tabular}


production and feeding rate (Figs $2 \& 4$ ). Averaged over the whole period 8 to 24 September, pellet production and body-carbon-specific ingestion rates were not significantly different between treatments (Table 6). The 'New SH1' series of females introduced into the experiment on 19 September showed significantly higher pellet production rates compared to all other treatments (Fig. 2, Table 7). However, due to a larger average body size in the 'New SH1' series (average $86 \mu \mathrm{gC}$ female ${ }^{-1}$, compared to $73 \mu \mathrm{gC}$ female ${ }^{-1}$ in 'New L1' series and ca $58 \mu \mathrm{gC}$ female ${ }^{-1}$ for all others), these females did not show higher carbon-specific feeding rates than the SH1, L1 or Rhodomonas baltica series (Fig. 4, Table 7). The carbon-specific ingestion rate may have been somewhat lower in the 'New L1' series (Table 7). Thus, there was no sign of experimentally introduced female fatigue, in

Table 4. Calanus helgolandicus. Copepod grazing experiments, cell counts. Average prey concentration and uncorrected values are calculated according to Frost (1972). Other values are corrected according to Eq. (1) \pm SD for the mean $(n=4)$. Prey preference (Manly's alpha) values are multiplied by 100 for convenience, values $>11.1$ indicate preferred food type. ${ }^{*} p<0.05,{ }^{* *} p<$ 0.01 and ${ }^{* * *} \mathrm{p}<0.001$ (2-tailed $t$-test) for Clearance and Ingestion $=0$, and Prey preference $=11.1$, respectively. Negative values were converted into zero before calculations of prey preference, total Ingestion and total daily body-carbon-specific ingestion rates (DR). DR $\left(\% \mathrm{C} \mathrm{d}^{-1}\right)$ is given in parentheses

\begin{tabular}{|c|c|c|c|c|c|c|c|}
\hline \multirow{2}{*}{$\begin{array}{l}\text { Expt } \\
\text { Prey type }\end{array}$} & \multirow{2}{*}{$\begin{array}{l}\text { Concentration } \\
\left(\mu \mathrm{C} \mathrm{C}^{-1}\right)\end{array}$} & \multicolumn{3}{|c|}{ Uncorrected values } & \multicolumn{3}{|c|}{ Corrected values } \\
\hline & & $\begin{array}{l}\text { Clearance } \\
\left(\mathrm{ml} \mathrm{d}^{-1}\right. \\
\left.\mathrm{cop}^{-1}\right)\end{array}$ & $\begin{array}{c}\text { Ingestion } \\
(\mu \mathrm{gC} \\
\left.\operatorname{cop}^{-1} \mathrm{~d}^{-1}\right)\end{array}$ & $\begin{array}{l}\text { Prey pref- } \\
\text { erence index } \\
\quad(\times 100)\end{array}$ & $\begin{array}{l}\text { Clearance } \\
\left(\mathrm{ml} \mathrm{d}^{-1}\right. \\
\left.\mathrm{cop}^{-1}\right)\end{array}$ & $\begin{array}{c}\text { Ingestion } \\
(\mu g C \\
\left.\operatorname{cop}^{-1} \mathrm{~d}^{-1}\right)\end{array}$ & $\begin{array}{l}\text { Prey pref- } \\
\text { erence index } \\
\qquad(\times 100)\end{array}$ \\
\hline \multicolumn{8}{|l|}{ L1a } \\
\hline Diatoms (9-15) & 47 & $17 \pm 17$ & $0.7 \pm 0.7$ & $4 \pm 3^{* *}$ & $54 \pm 25^{*}$ & $2.4 \pm 1.0^{*}$ & $13 \pm 0^{* * *}$ \\
\hline Flagellates (4-9) & 335 & $-16 \pm 0^{* * *}$ & $-5.7 \pm 0.2^{* * *}$ & $0 \pm 0^{* * *}$ & $-7 \pm 2^{* *}$ & $-2.6 \pm 0.8^{* *}$ & $0 \pm 0^{* * *}$ \\
\hline Flagellates $(10-18)$ & 287 & $47 \pm 16^{*}$ & $11.8 \pm 3.7^{* *}$ & $12 \pm 2$ & $47 \pm 16^{* *}$ & $11.8 \pm 3.7^{* *}$ & $11 \pm 2$ \\
\hline Ebria $(23-25)$ & 7 & $99 \pm 123$ & $0.5 \pm 0.5$ & $16 \pm 16$ & $99 \pm 123$ & $0.5 \pm 0.5$ & $15 \pm 14$ \\
\hline Dinoflagellates $(12-24)^{\mathrm{a}}$ & 33 & $53 \pm 27^{*}$ & $1.5 \pm 0.6^{*}$ & $13 \pm 2$ & $53 \pm 27^{*}$ & $1.5 \pm 0.6^{*}$ & $11 \pm 2$ \\
\hline Ciliates $(10-24)$ & 14 & $8 \pm 17$ & $0.1 \pm 0.2$ & $2 \pm 1^{* * *}$ & $8 \pm 17$ & $0.1 \pm 0.2$ & $2 \pm 3^{* *}$ \\
\hline Ciliates $(31-84)^{\mathrm{b}}$ & 29 & $136 \pm 16^{* * *}$ & $2.7 \pm 0.1^{* * *}$ & $29 \pm 12$ & $136 \pm 16^{* * *}$ & $2.7 \pm 0.1^{* * *}$ & $27 \pm 11$ \\
\hline Metazoa (65-255) & 2 & $111 \pm 54^{*}$ & $0.2 \pm 0.1^{*}$ & $24 \pm 2^{* *}$ & $111 \pm 54^{*}$ & $0.2 \pm 0.1^{*}$ & $22 \pm 2^{* *}$ \\
\hline Total & 754 & & $17.4(26.2)$ & & & $19.1(28.8)$ & \\
\hline \multicolumn{8}{|l|}{ L1b } \\
\hline Diatoms (9-15) & 46 & $33 \pm 35$ & $1.3 \pm 1.4$ & $7 \pm 8$ & $33 \pm 35$ & $1.3 \pm 1.4$ & $5 \pm 5$ \\
\hline Flagellates (4-9) & 165 & $7 \pm 36$ & $0.9 \pm 5.8$ & $1 \pm 2^{* * *}$ & $31 \pm 35$ & $4.8 \pm 5.3$ & $5 \pm 6$ \\
\hline Flagellates $(10-18)$ & 120 & $1 \pm 18$ & $0.0 \pm 2.2$ & $0 \pm 0^{* * *}$ & $1 \pm 18$ & $0.0 \pm 2.2$ & $0 \pm 3^{* *}$ \\
\hline Ebria $(23-25)$ & 8 & $-10 \pm 11$ & $-0.1 \pm 0.1$ & $0 \pm 0^{* * *}$ & $41 \pm 13^{* *}$ & $0.3 \pm 0.1^{* *}$ & $5 \pm 2^{*}$ \\
\hline Dinoflagellates $(12-24)^{\mathrm{a}}$ & 81 & $13 \pm 0^{* * *}$ & $1.0 \pm 0.0^{* * *}$ & $3 \pm 1^{* * *}$ & $63 \pm 2^{* * *}$ & $5.0 \pm 0.2^{* * *}$ & $12 \pm 3$ \\
\hline Ciliates $(10-24)$ & 7 & $30 \pm 32$ & $0.2 \pm 0.2$ & $7 \pm 7$ & $81 \pm 30^{*}$ & $0.5 \pm 0.2^{*}$ & $14 \pm 4$ \\
\hline Ciliates $(31-84)^{\mathrm{b}}$ & 88 & $395 \pm 4^{* * *}$ & $13.5 \pm 0.4^{* * *}$ & $42 \pm 2^{* * *}$ & $395 \pm 4^{* * *}$ & $13.5 \pm 0.4^{* * *}$ & $31 \pm 3^{* *}$ \\
\hline Metazoa (65-255) & 15 & $258 \pm 93^{*}$ & $2.1 \pm 0.4^{* *}$ & $39 \pm 13^{*}$ & $258 \pm 93^{*}$ & $2.1 \pm 0.4^{* *}$ & $28 \pm 11$ \\
\hline Total & 530 & & $18.9(25.4)$ & & & $27.5(37.0)$ & \\
\hline \multicolumn{8}{|l|}{ H1a } \\
\hline Diatoms (9-15) & 90 & $-32 \pm 10^{* *}$ & $-3.2 \pm 1.0^{* *}$ & $0 \pm 0^{* * *}$ & $46 \pm 41$ & $4.5 \pm 3.9$ & $7 \pm 5$ \\
\hline Flagellates (4-9) & 374 & $-58 \pm 1^{* * *}$ & $-25.5 \pm 0.4^{* * *}$ & $0 \pm 0^{* * *}$ & $0 \pm 22$ & $0.1 \pm 9.8$ & $0 \pm 0^{* * *}$ \\
\hline Flagellates (10-18) & 149 & $-115 \pm 2^{* * *}$ & $-23.8 \pm 0.7^{* * *}$ & $0 \pm 0^{* * *}$ & $-22 \pm 39$ & $-4.6 \pm 8.1$ & $0 \pm 0^{* * *}$ \\
\hline Ebria $(23-25)$ & 3 & $26 \pm 27$ & $0.1 \pm 0.1$ & $7 \pm 6$ & $113 \pm 8^{* * *}$ & $0.3 \pm 0.0^{* * *}$ & $17 \pm 3^{* *}$ \\
\hline Dinoflagellates $(12-24)^{a}$ & 5 & $-66 \pm 10^{* * *}$ & $-0.4 \pm 0.1^{* *}$ & $0 \pm 0^{* * *}$ & $21 \pm 25$ & $0.1 \pm 0.2$ & $3 \pm 4^{*}$ \\
\hline Ciliates $(10-24)$ & 10 & $65 \pm 29^{*}$ & $0.5 \pm 0.2^{*}$ & $17 \pm 6$ & $155 \pm 7^{* * *}$ & $1.3 \pm 0.1^{* * *}$ & $23 \pm 6^{* *}$ \\
\hline Ciliates $(31-84)^{\mathrm{b}}$ & 20 & $160 \pm 29^{* *}$ & $2.1 \pm 0.2^{* * *}$ & $33 \pm 5^{* *}$ & $160 \pm 29^{* *}$ & $2.1 \pm 0.2^{* *}$ & $18 \pm 4^{*}$ \\
\hline Metazoa (65-255) & 6 & $224 \pm 32^{* * *}$ & $0.9 \pm 0.1^{* * *}$ & $44 \pm 8^{* *}$ & $224 \pm 32^{* * *}$ & $1.2 \pm 0.5^{* * *}$ & $31 \pm 6^{* *}$ \\
\hline Total & 658 & & $3.8(4.5)$ & & & $9.6(13.2)$ & \\
\hline \multicolumn{8}{|l|}{ SH1b } \\
\hline Diatoms (9-15) & 918 & $6 \pm 27$ & $4.2 \pm 23.9$ & $1 \pm 0^{* * *}$ & $37 \pm 33$ & $32.1 \pm 28.2$ & $6 \pm 4^{*}$ \\
\hline Flagellates (4-9) & 375 & $-48 \pm 24^{*}$ & $-20.7 \pm 11.2^{*}$ & $0 \pm 0^{* * *}$ & $-26 \pm 29$ & $-11.2 \pm 12.7$ & $0 \pm 0^{* * *}$ \\
\hline Flagellates (10-18) & 187 & $31 \pm 53$ & $4.8 \pm 8.5$ & $6 \pm 2^{* *}$ & $31 \pm 53$ & $4.8 \pm 8.5$ & $5 \pm 2^{* *}$ \\
\hline Ebria $(23-25)$ & 16 & $11 \pm 6^{*}$ & $0.2 \pm 0.1^{*}$ & $2 \pm 1^{* * *}$ & $59 \pm 16^{* *}$ & $0.9 \pm 0.2^{* *}$ & $10 \pm 1^{*}$ \\
\hline Dinoflagellates $(12-24)^{\mathrm{a}}$ & 7 & $-79 \pm 14^{* *}$ & $-0.7 \pm 0.1^{* *}$ & $0 \pm 0^{* * *}$ & $-31 \pm 4^{* * *}$ & $-0.3 \pm 0.0^{* * *}$ & $0 \pm 0^{* * *}$ \\
\hline Ciliates $(10-24)$ & 2 & $77 \pm 117$ & $0.1 \pm 0.2$ & $13 \pm 21$ & $125 \pm 128$ & $0.2 \pm 0.2$ & $18 \pm 16$ \\
\hline Ciliates $(31-84)^{\mathrm{b}}$ & 30 & $335 \pm 115^{*}$ & $4.9 \pm 0.8^{* *}$ & $41 \pm 2^{* * *}$ & $335 \pm 115^{*}$ & $4.9 \pm 0.8^{* *}$ & $32 \pm 3^{* * *}$ \\
\hline Metazoa (65-255) & 5 & $235 \pm 29^{* * *}$ & $0.8 \pm 0.1^{* * *}$ & $36 \pm 17$ & $235 \pm 29^{* * *}$ & $0.8 \pm 0.1^{* * *}$ & $29 \pm 14$ \\
\hline Total & 1540 & & $14.9(19.8)$ & & & $43.4(57.7)$ & \\
\hline
\end{tabular}


Table 5. Calanus helgolandicus. Copepod grazing experiments, chl a $>0.45 \mu \mathrm{m}$. Body-carbon-specific ingestion rates (DR) is based on minimum (min.) and maximum (max.) algae chl a:C factors of 20 and 100, respectively. Otherwise as Table 4

\begin{tabular}{|c|c|c|c|c|c|c|c|}
\hline \multirow[t]{2}{*}{ Expt } & \multirow{2}{*}{$\begin{array}{c}\text { Chl } a \\
\text { concentration } \\
\left(\mu \mathrm{g} \mathrm{l}^{-1}\right)\end{array}$} & \multicolumn{3}{|c|}{ Uncorrected values } & \multicolumn{3}{|c|}{ Corrected values } \\
\hline & & $\begin{array}{l}\text { Clearance } \\
\left(\mathrm{ml} \mathrm{d}^{-1}\right. \\
\left.\mathrm{cop}^{-1}\right)\end{array}$ & $\begin{array}{c}\text { Ingestion } \\
(\mu \mathrm{g} \mathrm{chl} \mathrm{a} \\
\left.\mathrm{cop}^{-1} \mathrm{~d}^{-1}\right)\end{array}$ & $\begin{array}{c}\text { DR } \\
\left(\% \mathrm{C} \mathrm{copC}^{-1} \mathrm{~d}^{-1}\right) \\
\min ., \max .\end{array}$ & $\begin{array}{c}\text { Clearance } \\
\left(\mathrm{ml} \mathrm{d}^{-1} \mathrm{cop}^{-1}\right)\end{array}$ & $\begin{array}{l}\text { Ingestion } \\
(\mu \mathrm{g} \text { chl } a \\
\left.\operatorname{cop}^{-1} \mathrm{~d}^{-1}\right)\end{array}$ & $\begin{array}{c}\mathrm{DR} \\
\left.\% \mathrm{C} \operatorname{copC}^{-1} \mathrm{~d}^{-1}\right) \\
\min ., \max .\end{array}$ \\
\hline L1a & 4 & $-2 \pm 9$ & $-0.01 \pm 0.04$ & & $13 \pm 8^{*}$ & $0.05 \pm 0.03^{*}$ & $2-8$ \\
\hline L1b & 6 & $4 \pm 6$ & $0.02 \pm 0.03$ & $1-3$ & $47 \pm 6^{* * *}$ & $0.28 \pm 0.03^{* * *}$ & $8-38$ \\
\hline SH1a & 5 & $8 \pm 32$ & $0.03 \pm 0.15$ & $1-4$ & $42 \pm 37$ & $0.20 \pm 0.16$ & $6-28$ \\
\hline SH1b & 10 & $22 \pm 3^{* * *}$ & $0.22 \pm 0.02^{* * *}$ & $6-29$ & $89 \pm 11^{* * *}$ & $0.87 \pm 0.11^{* * *}$ & $23-116$ \\
\hline
\end{tabular}

terms of feeding rates in females kept throughout the experimental period.

There was, however, a difference in development of the feeding over time between the treatments. In the

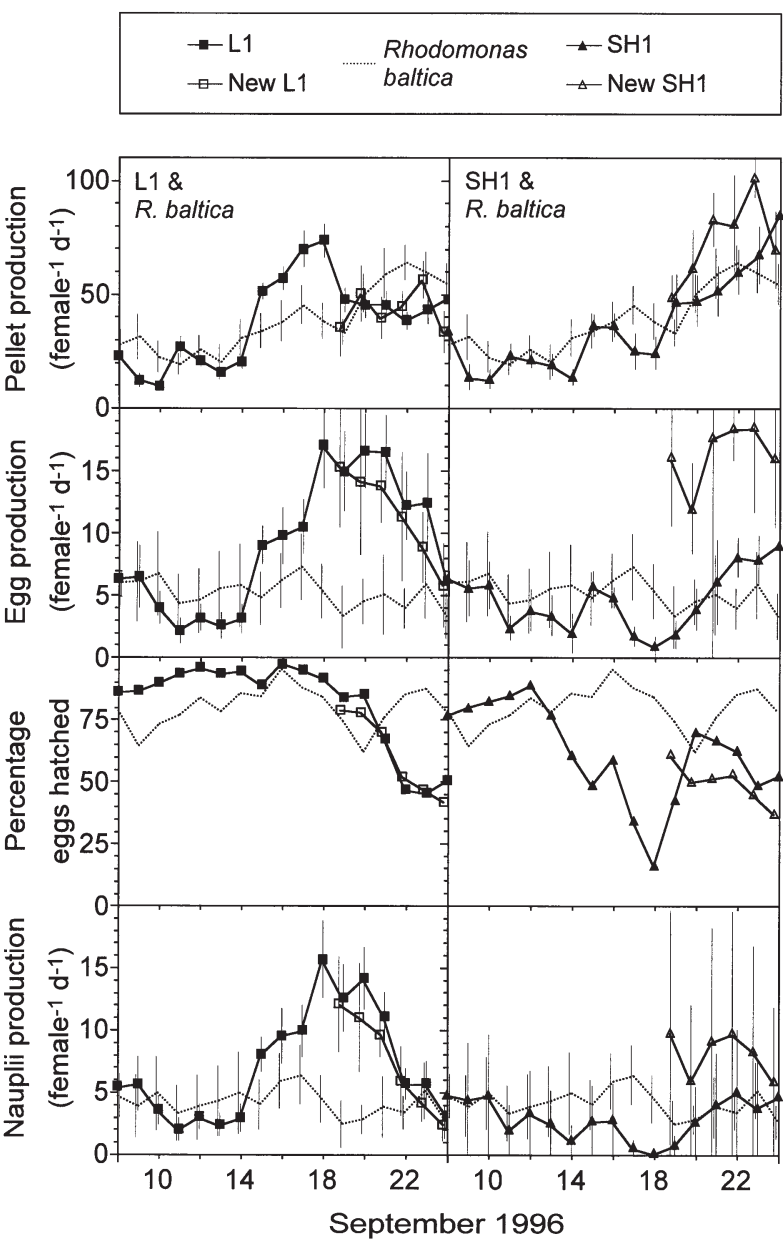

Fig. 2. Calanus helgolandicus. Faecal pellet, egg and nauplii production per female fed in the water from the mesocosms or a monoculture of Rhodomonas baltica between 8 and 24 September 1996. Y-error bars $=95 \%$ confidence intervals of means, $\mathrm{n}=24$ ( $R$. baltica), 26 (SH1) and 30 (L1). For hatching $\% \mathrm{n}=1$ (1 joint sample analysed for each treatment and day)
L1 series the maximum feeding activity coincided with the maximum abundance of the preferred larger-sized microzooplankton prey between ca 14 and 19 September, while the lowest rates coincided with a dominance of the non-preferred small flagellates and Dictyocha speculum in the food suspension (cf. Figs 1, 2 \& 4, Table 4, L1b). Females kept in water from the SH1 mesocosm showed a gradual increase in feeding rate (Figs $2 \& 4$, Table 4) concomitant with the increase in all food types except the nanoflagellates (Fig. 1).

Egg production in the L1 and SH1 series was lower than in the Rhodomonas baltica series (only significant for L1, p < 0.05) when the total food abundance was between 150 and $300 \mu \mathrm{gC} \mathrm{l}^{-1}$ and was dominated by nanoflagellates in both mesocosms (Figs 1, 2 \& 4). However, when the biomass of larger microzooplankton, dinoflagellates and total prey reached maxima of 160,84 , and $370 \mu \mathrm{gC}^{-1}$ respectively, on 16 September in the L1 mesocosm, egg production increased to a maximum of ca 17 eggs female $\mathrm{e}^{-1} \mathrm{~d}^{-1}$ on 18 September (Figs 1, 2 \& 4). During the shift from microzooplankton/dinoflagellate to nanoflagellate/Dictyocha speculum dominance in the L1 mesocosm, egg production decreased for both series to rates comparable to initial values (Figs $2 \& 4$ ). Hatching success was generally

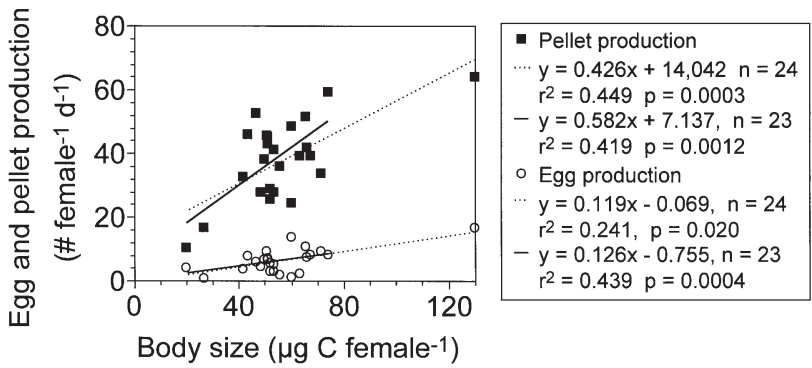

Fig. 3. Calanus helgolandicus. Correlation between female body size and pellet and egg production. Mean daily rates are calculated for the period 8 to 24 September for females fed Rhodomonas baltica. Linear regressions are fitted to the respective data, with the $130 \mu \mathrm{g}$ C-outlier both included ( $\mathrm{n}=24$, hatched lines), and excluded $(\mathrm{n}=23$, solid lines) 


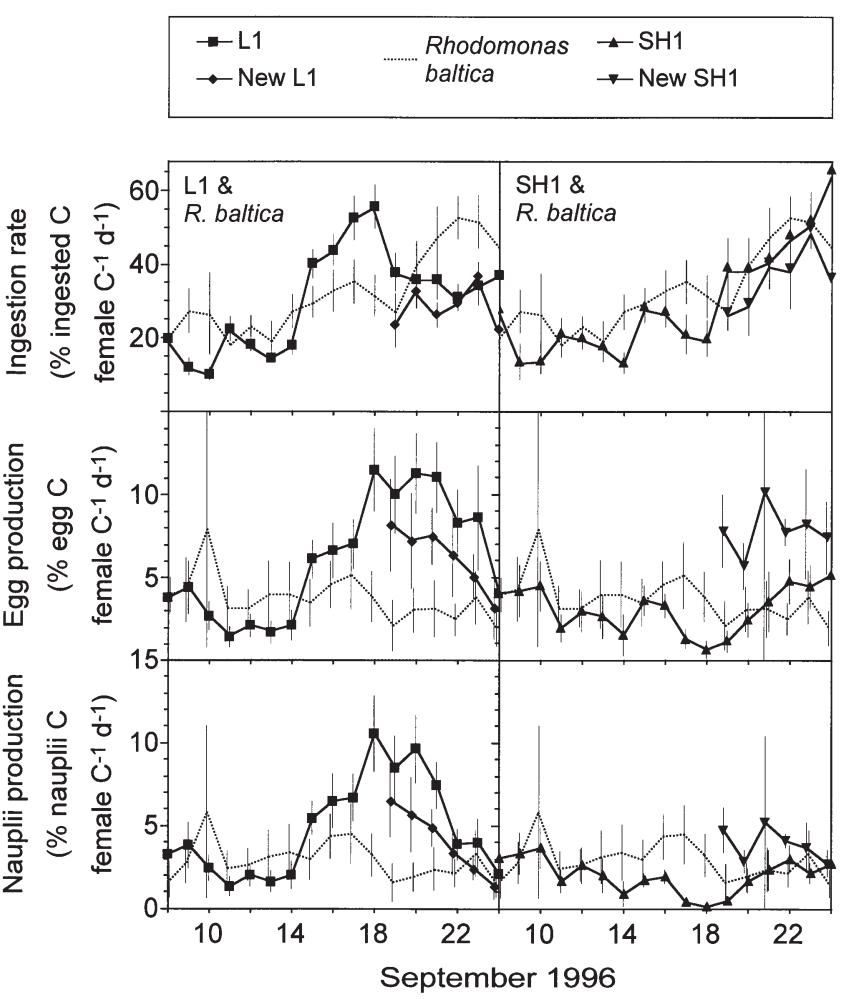

Fig. 4. Calanus helgolandicus. Female body-carbon-specific ingestion rate, egg and nauplii production. Ingestion rates are converted from faecal pellet production (Fig. 2) using Eqs (5) \& (6). Nauplii production is calculated as egg C multiplied by the fraction of hatched eggs. Annotations are otherwise as in Fig. 2

high (70 to $95 \%$ ) for the L1 and $R$. baltica series, but there was a significant drop in hatching success (minimum ca $45 \%$ ) and egg production for both the L1 and 'New L1' during the nanoflagellate/D. speculum bloom (Figs $2 \& 4$ ).

In the SH1 series there was a profound drop in both egg production and hatching success during the diatom increase, between 16 and 20 September, despite a general increase in feeding rate during the period of the experiment (Figs $2 \& 4$ ). On 18 September, when the diatom and total prey concentrations were 270 and $580 \mu \mathrm{gC} \mathrm{l}^{-1}$ respectively, hatching success fell to its minimum of $15 \%$ and the number of hatched eggs was $<0.15$ female $^{-1} \mathrm{~d}^{-1}$ (Figs 1, 2 \& 4). During the last part of the experiment, egg production and hatching success increased again in the SH1 series, but nauplii production only reached the initial values despite the fact that feeding rates were 2 to $2.5 \times$ higher than at the start of the experiment (Figs 1, 2 \& 4). The 'New SH1' copepods were exposed to the water from the SH1 mesocosm after the lowest values were recorded in the SH1 series; the 'New SH1' series showed a significantly higher egg and nauplii production but the hatching success and ingestion rate were similar or lower compared to the old SH1 series (Figs 2 \& 4, Table 7).

Average egg and nauplii production was significantly higher in the L1 and 'New L1' treatments compared to all other treatments except 'New SH1', both in terms of numbers and carbon (Figs $2 \& 4$, Table 7). However, compared to the 'New SH1' series, the L1 series also showed significantly higher food conversion efficiency into nauplii (Table 7). Thus, in general, copepods fed in the diatom-dominated waters showed significantly lower reproductive success, especially in terms of food to nauplii conversion rates.

Table 6. Calanus helgolandicus. Average ingestion, pellet production, egg production and nauplii production rates, and conversion efficiencies, between 8 and 24 September. Multiple comparisons between treatments (Games-Howell post hoc test, $\mathrm{n}=24-30),{ }^{*} \mathrm{p}<0.05,{ }^{* *} \mathrm{p}<0.01$, and ${ }^{* * *} \mathrm{p}<0.001$. Ingestion rates and food conversion efficiencies are derived from faecal pellet production and Eqs (5) \& (6)

\begin{tabular}{|c|c|c|c|}
\hline Series & Average & Rhodomonas & SH1 \\
\hline \multicolumn{4}{|c|}{ Pellet production (pellet female ${ }^{-1} \mathrm{~d}^{-1}$ ) } \\
\hline L1 & 38 & & \\
\hline SH1 & 33 & & \\
\hline Rhodomonas & 39 & & \\
\hline \multicolumn{4}{|c|}{ Carbon-specific ingestion ( $\%$ ingested $\mathrm{C}$ female $\mathrm{C}^{-1} \mathrm{~d}^{-1}$ ) } \\
\hline L1 & 30 & & \\
\hline SH1 & 27 & & \\
\hline Rhodomonas & 31 & & \\
\hline \multicolumn{4}{|c|}{ Egg production (egg female ${ }^{-1} \mathrm{~d}^{-1}$ ) } \\
\hline L1 & 9.0 & *** & *** \\
\hline SH1 & 4.4 & & \\
\hline Rhodomonas & 5.6 & & \\
\hline \multicolumn{4}{|c|}{ Carbon-specific egg production (\% egg $\mathrm{C}$ female $\mathrm{C}^{-1} \mathrm{~d}^{-1}$ ) } \\
\hline L1 & 6.0 & **** & *** \\
\hline SH1 & 3.1 & & \\
\hline Rhodomonas & 3.8 & & \\
\hline \multicolumn{4}{|c|}{ Nauplii production (nauplii female $\mathrm{e}^{-1} \mathrm{~d}^{-1}$ ) } \\
\hline L1 & 7.1 & *** & *** \\
\hline SH1 & 2.9 & * & \\
\hline Rhodomonas & 4.4 & & \\
\hline \multicolumn{4}{|c|}{$\begin{array}{l}\text { Carbon-specific nauplii production (\% nauplii } \mathrm{C} \text { female } \\
\mathrm{C}^{-1} \mathrm{~d}^{-1} \text { ) }\end{array}$} \\
\hline L1 & 4.8 & $* * *$ & $* * *$ \\
\hline SH1 & 2.0 & $*$ & \\
\hline Rhodomonas & 2.9 & & \\
\hline \multicolumn{4}{|c|}{ Food to egg conversion efficiency ( $\%$ egg $C$ ingested $C^{-1}$ ) } \\
\hline L1 & 20 & $* * *$ & $* * *$ \\
\hline SH1 & 11 & & \\
\hline Rhodomonas & 12 & & \\
\hline \multicolumn{4}{|c|}{$\begin{array}{l}\text { Food to nauplii conversion efficiency (\% nauplii } \mathrm{C} \text { in- } \\
\text { gested } \mathrm{C}^{-1} \text { ) }\end{array}$} \\
\hline L1 & 15 & $* * *$ & $* * *$ \\
\hline SH1 & 8 & & \\
\hline Rhodomonas & 9 & & \\
\hline
\end{tabular}




\section{Development of mesozooplankton in the mesocosms}

There was very little variation in the zooplankton community between the initial samples (Fig. 5). However, at the termination of the experiment, the average

Table 7. Calanus helgolandicus. Multiple comparisons of values from all series averaged for the latter part of the egg production experiment between 19 and 24 September. Otherwise as Table 6

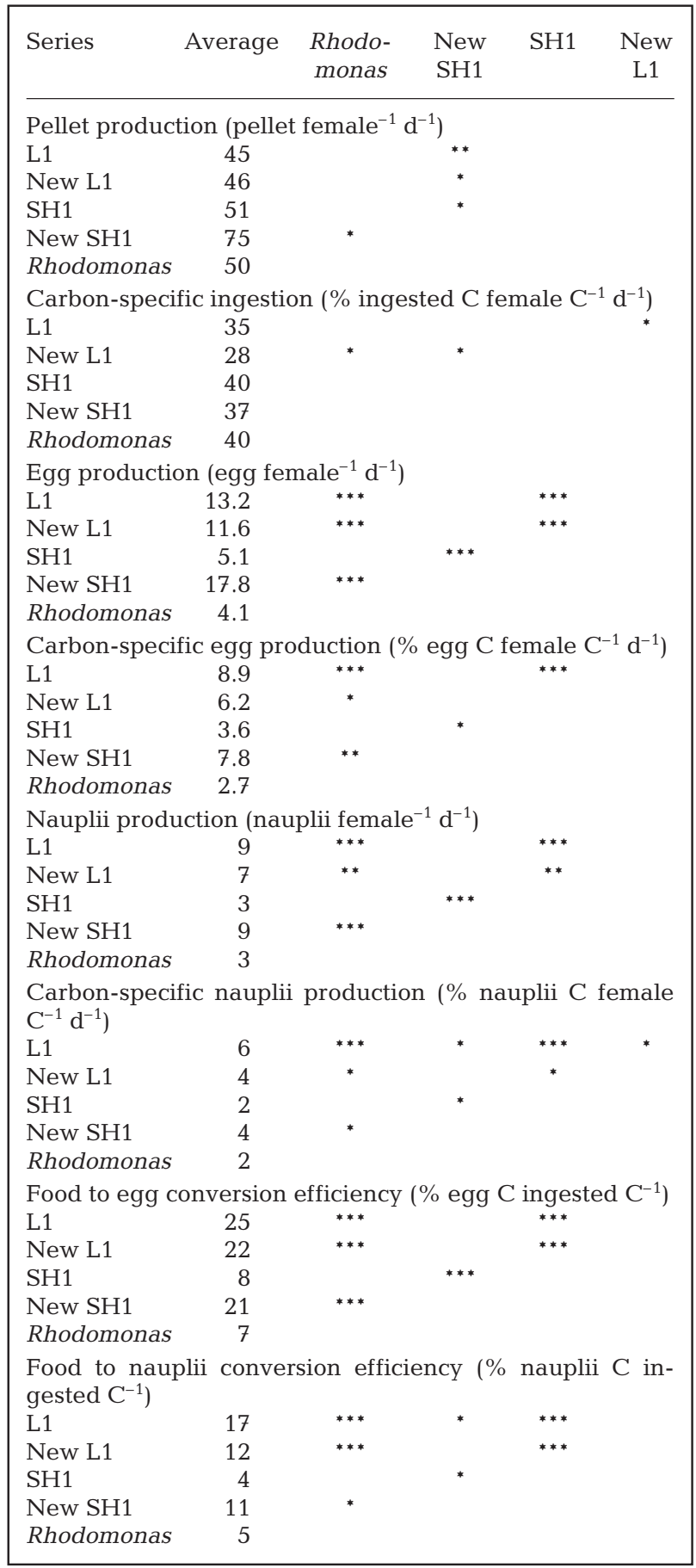

biomass of calanoid copepods in the mesocosms without Si-addition $\left(40 \mu \mathrm{gC} \mathrm{m} \mathrm{m}^{-3}\right)$ was significantly higher both compared to the initial concentration $\left(15 \mu \mathrm{gC} \mathrm{m}^{-3}\right.$, $\mathrm{p}<0.005$, Scheffé's test), and to the Si-added mesocosms $\left(25 \mu \mathrm{gC} \mathrm{m}{ }^{-3}, \mathrm{p}<0.036\right)$. This corresponds to a 2.6-fold higher net increase in the mesocosms without $\mathrm{Si}$ addition. As the calanoid copepods dominated the total biomass of zooplankton $>90 \mu \mathrm{m}$, this was also reflected in the average total concentrations of 17, 34 and $60 \mu \mathrm{gC} \mathrm{m}{ }^{-3}$, in initial samples, Si-added, and nonSi mesocosms, respectively. The concentration of total zooplankton $>90 \mu \mathrm{m}$ in the non-Si mesocosm was significantly different from both initial $(p<0.002)$, and Si-added mesocosm concentrations $(p<0.017)$. This corresponds to a 2.7-fold higher net increase of total zooplankton $>90 \mu \mathrm{m}$ in the mesocosms without $\mathrm{Si}$ addition. Although the other copepods (mostly the cyclopoid Oithona spp.) and other zooplankton were, respectively, an average of $1.6 \times$ and $6.4 \times$ as abundant in the non-Si mesocosms at the termination of the mesocosm experiment, this was not statistically significant ( $p=0.11$ to 0.99 ) due to large variations within the treatments.

\section{DISCUSSION}

\section{Mesocosms: methodological considerations}

Compared to laboratory experiments, sea water enclosures offer a more realistic environment for ecological studies, with a larger volume and inclusion of a higher number of trophic levels. However, advective processes are excluded, and 'bag effects' such as accelerated plankton succession may also be important (Davis 1982). Thus, extrapolations of results from mesocosm experiments to the natural environment should be carried out with caution.

However, previous enclosure experiments from western Norway have shown close similarities between untreated control enclosures and the surrounding sea, while experimental treatments have shown similar development in parallel enclosures (Dale 1988, Egge 1993, Egge \& Jacobsen 1997). Furthermore, the nutrient manipulations were kept within natural prespring bloom values, and the abundance of copepods and algae in the present mesocosms were within observed values in Norwegian fjords and coastal waters (e.g. Birkenes \& Braarud 1952, Wiborg 1954, Paasche \& Østergren 1980, Erga \& Heimdal 1984). For example, the maximum biomass of diatoms $(307 \mu \mathrm{gC}$ $\mathrm{l}^{-1}$, dominated by Skeletonema costatum) and total phytoplankton $\left(695 \mu \mathrm{gC} \mathrm{l}^{-1}\right)$ were well within bloom concentrations of diatoms (840 to $1140 \mu \mathrm{gC}^{-1}$, dominated by $S$. costatum) and total phytoplankton (850 to 


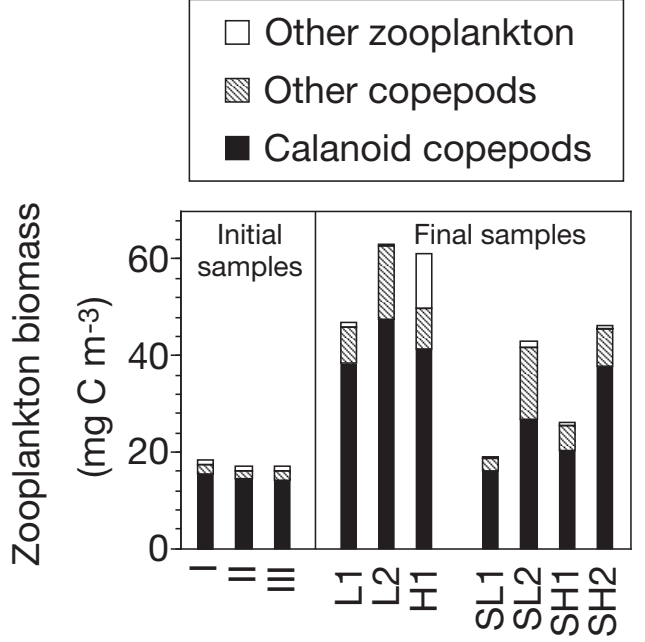

Fig. 5. Zooplankton $>90 \mu \mathrm{m}$ in the water used to fill the mesocosms on 28 August (Initial samples I to III), and sampled from the entire mesocosms at the termination of the experiment on 28 September (Final samples, L1 to SH2). Calanoid copepods were composed of $>16$ species, dominated by Calanus spp., Pseudocalanus spp., Paracalanus parvus and Temora longicornis. Other copepods were mainly Oithona spp. Other plankton was mainly meroplanktonic forms ( $>24$ taxa)

$1610 \mu \mathrm{gC}^{-1}$ ) in the Oslofjord (Paasche \& Østergren 1980). Maximum ciliate concentration in the meso-

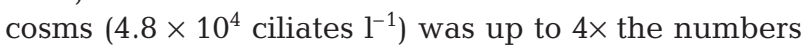
normally encountered during natural blooms in coastal waters (Smetacek 1981, Erga \& Heimdal 1984, Dale 1988). Ciliates may, however, reach higher abundances in coastal waters $\left(10^{5}\right.$ to $\left.10^{6} \mathrm{l}^{-1}\right)$ when conditions are favourable (Andersen \& Sørensen 1986, Dale \& Dahl 1987).

The data presented here should therefore be applicable to natural plankton, and mesocosm studies such as this provide an opportunity to compare several cohorts of copepods with a defined feeding history throughout the entire bloom cycles. In contrast, field studies aimed at quantifying the dietary effect of diatoms on copepod reproductive success are still limited. The observed large variability, and the inability to establish direct correlations between in situ prey items and copepod reproductive success in field studies may not be due to lack of a relationship per se, but rather to a methodological problem (see 'Introduction').

\section{Maximal egg production rates, body size and physiological status of the copepods}

The maximal average egg production was ca 17 eggs female ${ }^{-1} \mathrm{~d}^{-1}$ for Calanus helgolandicus in the L1 series.
This appears to be low compared to the maximum of 30 to 60 eggs female ${ }^{-1} \mathrm{~d}^{-1}$ previously reported for C. helgolandicus in field studies (Bautista et al. 1994, Pond et al. 1996, Laabir et al. 1998). However, in the present study the females were slender and the body carbon content was low (average $58 \mu \mathrm{gC}$ female $^{-1}$ in the SH1, L1 and Rhodomonas baltica series), suggesting that females did not have significant lipid stores and that egg production was therefore directly dependent on ingestion. Thus, the maximal egg production rate observed in the L1 series was relatively high in terms of body carbon $\mathrm{d}^{-1}\left(11.4 \%, 17\right.$ eggs $\left.\times 0.387 \mu \mathrm{gC} \mathrm{egg}^{-1}\right)$. Also, the average carbon-specific egg production rates of $3.1,3.8$ and $6.0 \%$ body C female ${ }^{-1} \mathrm{~d}^{-1}$, for the SH1, Rhodomonas and L1 series respectively, was well within previously reported results. For the sibling species $C$. finmarchicus, average egg production rates corresponded to 2.1 to $8.5 \%$ body $\mathrm{C}$ female $\mathrm{d}^{-1} \mathrm{~d}^{-1}$, depending on season and temperature (Hirche et al. 1997), and $11 \%$ body C female ${ }^{-1} \mathrm{~d}^{-1}$ in cultures of $R$. baltica similar to those used here (Båmstedt et al. 1999). Thus it seems that the egg production rates obtained in the L1 series were close to maximum, while the other treatments yielded egg production rates within the lower end of previously reported results.

\section{Diets and copepod reproductive success}

Calanus helgolandicus always showed the highest feeding rates for larger microzooplankton (Table 4), and showed a reproduction peak during the bloom of ciliates, metazoa and dinoflagellates in L1 (Figs 1, 2 \& 4). This is in accordance with previous mesocosm experiments with Calanus spp. (Nejstgaard et al. 1994, Nejstgaard et al. 1997, Nejstgaard et al. 2001), and other reports from coastal waters (see 'Introduction'). The results (Fig. 4) also suggest that the natural plankton dominated by ciliates, metazoa and dinoflagellates was a much better food than Rhodomonas baltica in surplus concentrations (ca $900 \mu \mathrm{gC} \mathrm{l}^{-1}$, Båmstedt et al. 1999), despite the fact that $R$. baltica is often used as food for copepod cultures (Støttrup \& Jensen 1990), and may support relatively high reproduction in Calanus finmarchicus (Båmstedt et al. 1999).

Nauplii production in Calanus helgolandicus decreased 5-fold during the shift from dinoflagellate/ microzooplankton-dominated to flagellate/Dictyocha speculum-dominated food suspensions (Figs 1 \& 4, L1 between 18 and 24 September). This may be due both to reduced feeding activity, as indicated by the reduced pellet production, and reduced food quality, since the reproductive output dropped rapidly (Fig. 4). Flagellates and $D$. speculum were not preferred food and contributed only to a limited fraction of the 
ingested prey (Table 4). Although the small flagellates may be inefficiently grazed due to their sub-optimal size, the silicoflagellate (12 to $15 \mu \mathrm{m}$ ESD) should not be too small for efficient predation by Calanus (cf. Hansen et al. 1994). This is, to our knowledge, the first observation that copepod feeding and reproduction may be reduced in blooms of this species in natural plankton. It has, however, been suggested that $D$. speculum may be toxic to fish (Bjergskov et al. 1990). Although feeding and reproduction was reduced in flagellate $/ D$. speculum-dominated food suspensions for both series (Fig. 4), only the 'New L1' series showed nauplii production below that of the Rhodomones baltica-series (Fig. 4).

When diatoms, flagellates $<10 \mu \mathrm{m}$ and Dictyocha speculum dominated the food suspension in SH1, reproductive output dropped to virtually zero $(0.1 \%$ nauplii $\mathrm{C}$ female $\mathrm{C}^{-1} \mathrm{~d}^{-1}$ ) on 18 September (Figs $1 \& 4$ ). Phytoplankton growth conditions (e.g. Jónasdóttir 1994) and feeding regimes for microzooplankton (cf. Kleppel \& Burkart 1995, Klein Breteler et al. 1999) are important for the nutritional composition of the cells. Thus, taxonomic composition of the food does not equal nutritional value for the predator. However, as shown in L1 and discussed above, mixed natural diets with significant contribution of microzooplankton and other carnivore prey often sustain both high food conversion efficiencies (cf. Mauchline 1998) and high copepod egg production rates. If we assume that the diatom/Dictyocha speculum/flagellate diet is nutritionally insufficient to sustain any nauplii production, and that there are no complementary nutritional effects (as described in Kleppel \& Burkart 1995 and Schmidt \& Jónasdóttir 1997), we would still expect some nauplii production, provided that metazoa and ciliate prey contribute to a nutritionally adequate diet.

If we assume a $30 \%$ production efficiency (see references in Mauchline 1998, Richardson et al. 1999), the ingestion of ciliates and metazoa in SH1b $(5.8 \mu \mathrm{gC}$ copepod $^{-1} \mathrm{~d}^{-1}=7.7 \%$ body $\mathrm{C} \mathrm{d}^{-1}$, Table 4 ) may correspond to a $2.3 \%$ daily egg $\mathrm{C}$ production hatching into nauplii, whereas a maximal egg $C$ production based on total daily $\mathrm{C}$ ratio (52\%, Table 4) corresponds to $16 \%$ female ${ }^{-1} \mathrm{~d}^{-1}$. However, the measured C-specific egg production and nauplii production $\left(0.9\right.$ and $\left.0.1 \% \mathrm{~d}^{-1}\right)$ were ca $20 \times$ lower. We suggest that these conspicuously low rates are either due to inhibititory substances in the plankton, and/or low nutrient quality of the algae, and that this low nutritional quality is also reflected in the dominating microzooplankton (i.e. ciliates) in SH1 before 18 September.

If the former assumption is true, this suggests that inhibitory components in diatoms (sensu Miralto et al. 1999) and/or possibly in Dictyocha speculum may be an important factor during such blooms, also when sig- nificant amounts of alternative prey are available. If the latter assumptions are true, this would support the hypothesis by Klein Breteler et al. (1999) that marine ciliates may lack the ability to add value to the food consumed, apart from repackaging it. This would further suggest that all the algae, including the smaller flagellates not actively grazed by the copepods, comprise a nutritionally poor diet for copepods. If this is so, we speculate that the increased reproduction after 18 September in SH1 (Fig. 4) was supported by trophic upgrading of food quality by the increasingly abundant dinoflagellates (sensu Klein Breteler et al. 1999).

In general, Calanus helgolandicus showed ca $2.4 \times$ higher average nauplii production rates in the flagellate/microzooplankton dominated water, compared to diatom-dominated water (Fig. 4). This was in good agreement with the development of the entire calanoid copepod populations, which increased on average $2.6 \times$ more in the flagellate/microzooplankton-dominated mesocosms, compared to the diatom-dominated mesocosms.

We believe that these data are the first to compare the development of egg and nauplii production of individual copepods simultaneously throughout defined, contrasting blooms of natural plankton, and at the same time compare the net production of the different mesozooplankton within these blooms, under otherwise similar conditions. A previous mesocosm study showed a lower total zooplankton biomass increase in 2 mesocosms dominated by diatoms compared to 2 mesocosms dominated by microzooplankton and the small coccolithophorid Emiliania huxleyi (Nejstgaard et al. 1997). That study also showed that female Calanus finmarchicus produced more eggs during a bloom of E. huxleyi than during blooms of Skeletonema costatum. However, in Nejstgaard et al. (1997) the egg production experiments were not run throughout the mesocosm experiment and hatching was not assessed. Nevertheless, both mesocosm experiments clearly show that total reproductive output of both $C$. helgolandicus and $C$. finmarchicus may be significantly reduced in blooms of natural plankton dominated by diatoms, compared to non-diatom blooms.

\section{Conclusions}

The non-diatom blooms both supported a significantly higher overall body-carbon-specific nauplii production and food to nauplii conversion efficiency in the Calanus helgolandicus egg production experiments, as well as a $2.6 \times$ net increase in the entire population of calanoid copepods in the mesocosms. The lowest reproductive success in the diatom-dominated environment was recorded when microzoo- 
plankton made up a substantial part of the diet. These results therefore suggest either that the ciliates did not upgrade the quality of their diatom food and/or that inhibitory components may be an important factor during diatom blooms, even when alternative prey is available. We also suggest that blooms of the silicoflagellate Dictyocha speculum may reduce copepod reproduction. The importance of nutritional composition versus inhibitory or toxicological properties of the food in natural environments is still poorly understood. Mesocosms provide excellent installations for such studies. With the recent development of techniques to determine the content of both deleterious components (e.g. Miralto et al. 1999), and nutritional value of the food (e.g. Jónasdóttir 1994, Kleppel et al. 1998), it appears that we now have the tools to perform such studies.

Acknowledgements. We acknowledge Jorun K. Egge and Urban Tillmann for providing data. We also acknowledge Sigrún H. Jónasdóttir, and 3 anonymous referees for their comments and suggestions to the manuscript. This work was supported by grants from the Norwegian Research Council for Science and Humanities (NFR) to J.C.N., L.-J.N. and U.B. as part of the MARICULT project NAPP. B.H.H. was supported by the Commission of the European Community through contract MAS3-CT95-0039 (TASC) and by the TMR (Training and Mobility of Researchers) programme from the European Union through contract ERBFMGECT950013. He also acknowledges the NOVO Nordic Foundation for grants for the image analysis system.

\section{LITERATURE CITED}

Andersen P, Sørensen HM (1986) Population dynamics and trophic coupling in pelagic microorganisms in eutrophic coastal waters. Mar Ecol Prog Ser 33:99-109

Båmstedt U (1986) Chemical composition and energy content. In: Corner EDS, O'Hara SCM (eds) The biological chemistry of marine copepods. Oxford University Press, Oxford, p 1-58

Båmstedt U, Håkanson JL, Brenner-Larsen J, Bjørnsen PK, Geertz-Hansen O, Tiselius P (1990) Copepod nutritional condition and pelagic production during autumn in Kosterfjorden, western Sweden. Mar Biol 104:197-208

Båmstedt U, Nejstgaard JC, Solberg PT (1999) Utilisation of small-sized food algae by Calanus finmarchicus (Copepoda, Calanoida) and the significance of feeding history. Sarsia 84:19-38

Båmstedt U, Gifford DJ, Irigoien X, Atkinson A, Roman M (2000) Feeding. In: Harris R, Wiebe P, Lenz J, Skjoldal HR, Huntley M (eds) ICES zooplankton methodology manual. Academic Press, London, p 297-399

Ban S, Burns C, Castel J, Chaudron Y, Christou E, Escribano R, Umani SF, Gasparini S, Ruiz FG, Hoffmeyer M, Ianora A, Kang HK, Laabir M, Lacoste A, Miralto A, Ning X, Poulet S, Rodriguez V, Runge J, Shi J, Starr M, Uye S, Wang Y (1997) The paradox of diatom-copepod interactions. Mar Ecol Prog Ser 157:287-293

Ban S, Lee HW, Shinada A, Toda T (2000) In situ egg production and hatching success of the marine copepod Pseudo- calanus newmani in Funka Bay and adjacent waters off southwestern Hokkaido, Japan: associated to diatom bloom. J Plankton Res 22:907-922

Bautista B, Harris RP, Rodriguez V, Guerrero F (1994) Temporal variability in copepod fecundity during two different spring bloom periods in coastal waters off Plymouth (SW England). J Plankton Res 16:1367-1377

Birkenes E, Braarud T (1952) Phytoplankton in the Oslo fjord during a 'Coccolithus huxleyi-summer'. Avhandlinger utgitt av Det Norske Videnskaps-Akademi i Oslo. I. Matematisk-Naturvidenskapelig Klasse 2:1-23

Bjergskov T, Larsen J, Moestrup Ø, Munk Sørensen H, Krogh P (1990) Toksiske og potentielt toksiske alger i danske farvande. Ministry of Fisheries, Copenhagen (in Danish and English)

Blom G, Otterå $H$, Svåsand T, Kristiansen TS, Serigstad B (1989) The relationship between feeding conditions and production of cod fry (Gadus morhua) in a semi-enclosed marine ecosystem in western Norway, illustrated by use of a consumption model. ICES Mar Sci Symp 192:176-189

Dale T (1988) Oil pollution and plankton dynamics. VI. Controlled ecosystem experiments in Lindåspollene, Norway, June 1981: effects on planktonic ciliates following nutrient addition to natural and oil-polluted enclosed water columns. Sarsia 73:179-191

Dale T, Dahl E (1987) Mass occurrence of planktonic oligotrichous ciliates in a bay in southern Norway. J Plankton Res $9871-879$

Davis CO (1982) The importance of understanding phytoplankton life strategies in the design of enclosure experiments. In: Griece GD, Reeve MR (eds) Marine mesocosms: biological and chemical research in experimental ecosystems. Springer-Verlag, New York, p 323-332

Edler L (1979) Recommendations for marine biological studies in the Baltic Sea: phytoplankton and chlorophyll. Baltic Mar Biol Publ 5:38

Egge JK (1993) Nutrient control of phytoplankton growth: effects of macronutrient composition $(\mathrm{N}, \mathrm{P}, \mathrm{Si})$ on species succession. Dr Scient thesis, University of Bergen

Egge JK, Jacobsen A (1997) Influence of silicate on particulate carbon production in phytoplankton. Mar Ecol Prog Ser 147:219-230

Erga SR, Heimdal BR (1984) Ecological studies on the phytoplankton of Korsfjorden, western Norway: the dynamics of a spring bloom seen in relation to hydrographical conditions and light regime. J Plankton Res 6:67-90

Frost BW (1972) Effect of size and concentration of food particles on the feeding behaviour of the marine planktonic copepod Calanus pacificus. Limnol Oceanogr 17:805-815

Gallegos CL (1989) Microzooplankton grazing on phytoplankton in the Rhode River, Maryland: nonlinear feeding kinetics. Mar Ecol Prog Ser 57:23-33

Games PA, Howell JF (1976) Pairwise multiple comparison procedures with unequal $n$ 's and/or variances: a Monte Carlo study. J Edu Stat 1:113-125

Hansen B, Bjørnsen PK, Hansen PJ (1994) The size ratio between planktonic predators and their prey. Limnol Oceanogr 39:395-403

Hirche HJ, Meyer U, Niehoff B (1997) Egg production of Calanus finmarchicus: effect of temperature, food and season. Mar Biol 127:609-620

Hook SE, Fisher NS (2001) Reproductive toxicity of metals in calanoid copepods. Mar Biol 138:1153-1161

Hygum BH, Rey C, Hansen BW (2000) Growth and development rates of Calanus finmarchicus nauplii during a diatom spring bloom. Mar Biol 136:1075-1085

Ianora A, Miralto A, Poulet SA (1999a) Are diatoms good or 
toxic for copepods? Reply to comment by Jónasdóttir et al. Mar Ecol Prog Ser 177:305-308

Ianora A, Miralto A, Buttino I, Romano G, Poulet SA (1999b) First evidence of some dinoflagellates reducing male copepod fertilization capacity. Limnol Oceanogr 44: $147-153$

Jónasdóttir SH (1994) Effects of food quality on the reproductive success of acartia tonsa and Acartia hudsonica: laboratory observations. Mar Biol 121:67-81

Jónasdóttir SH, Kiørboe T (1996) Copepod recruitment and food composition: do diatoms affect hatching success? Mar Biol 125:743-750

Jónasdóttir SH, Fields D, Pantoja S (1995) Copepod egg production in Long Island Sound, USA, as a function of the chemical composition of seston. Mar Ecol Prog Ser 119: 87-98

Jónasdóttir SH, Kiørboe T, Tang KW, St John M, Visser AW, Saiz E, Dam HG (1998) Role of diatoms in copepod production: good, harmless or toxic? Mar Ecol Prog Ser 172: 305-308

Karlson K, Båmstedt U (1994) Planktivorous predation on copepods: evaluation of mandible remains in predator guts as a quantitative estimate of predation. Mar Ecol Prog Ser 108:79-89

Kiørboe T, Tiselius PT (1987) Gut clearance and pigment destruction in a herbivorous copepod, Acartia tonsa, and the determination of in situ grazing rates. J Plankton Res 9:525-534

Klein Breteler WCM, Schogt N, Baas M, Schouten S, Kraay GW (1999) Trophic upgrading of food quality by protozoans enhancing copepod growth: role of essential lipids. Mar Biol 135:191-198

Kleppel GS (1993) On the diets of calanoid copepods. Mar Ecol Prog Ser 99:183-195

Kleppel GS, Burkart CA (1995) Egg production and the nutritional environment of Acartia tonsa: the role of food quality in copepod nutrition. ICES J Mar Sci 52:3-4

Kleppel GS, Holliday DV, Pieper RE (1991) Trophic interactions between copepods and microplankton: a question about the role of diatoms. Limnol Oceanogr 36:172-178

Kleppel GS, Burkart CA, Houchin L (1998) Nutrition and the regulation of egg production in the calanoid copepod Acartia tonsa. Limnol Oceanogr 43:1000-1007

Laabir M, Poulet SA, Ianora A, Miralto A, Cueff A (1995) Reproductive response of Calanus helgolandicus. II. In situ inhibition of embryonic development. Mar Ecol Prog Ser 129:1-3

Laabir M, Poulet SA, Harris RP, Pond DW, Cueff A, Head RN, Ianora A (1998) Comparative study of the reproduction of Calanus helgolandicus in well-mixed and seasonally stratified coastal waters of the western English Channel. J Plankton Res 20:407-421

Laabir M, Poulet SA, Cueff A, Ianora A (1999) Effect of diet on levels of amino acids during embryonic and naupliar development of the copepod Calanus helgolandicus. Mar Biol 134:89-98

Laabir M, Buttino I, Ianora A, Kattner G, Poulet SA, Romano G, Carotenuto Y, Miralto A (2001) Effect of specific dinoflagellate and diatom diets on gamete ultrastructure and fatty acid profiles of the copepod Temora stylifera. Mar Biol 138:1241-1250

Landry MR (1993) Estimating rates of growth and grazing mortality of phytoplankton by the dilution method. In: Kemp PF, Sherr BF, Sherr EB, Cole JJ (eds) Handbook of methods in aquatic microbial ecology. Lewis Publishers, Boca Raton, FL, p 715-722

Malej A, Harris RP (1993) Inhibition of copepod grazing by diatom exudates: a factor in the development of mucus aggregates? Mar Ecol Prog Ser 96:33-42

Manly BFJ (1974) A model for certain types of selection experiments. Biometrics 30:281-294

Mauchline J (1998) The biology of calanoid copepods. In: Blaxter JHS, Southward AJ, Tyler PA (eds) Advances in marine biology. Academic Press, San Diego

Menden-Deuer S, Lessard EJ (2000) Carbon to volume relationships for dinoflagellates, diatoms, and other protist plankton. Limnol Oceanogr 45:569-579

Miralto A, Barone G, Romano G, Poulet SA, Ianora A, Russo GL, Buttino I, Mazzarella G, Laabir M, Cabrinik M, Giacobbe MG (1999) The insidious effect of diatoms on copepod reproduction. Nature 402:173-176

Nejstgaard JC, Witte HJ, van der Wal P, Jacobsen A (1994) Copepod grazing during a mesocosm study of an Emiliania huxleyi (Prymnesiophyceae) bloom. Sarsia 79:369-377

Nejstgaard JC, Båmstedt U, Bagøien E, Solberg PT (1995) Algal constraints on copepod grazing. Growth state, toxicity, cell size, and season as regulating factors. ICES J Mar Sci 52:347-357

Nejstgaard JC, Gismervik I, Solberg PT (1997) Feeding and reproduction by Calanus finmarchicus, and microzooplankton grazing during mesocosm blooms of diatoms and the coccolithophore Emiliania huxleyi. Mar Ecol Prog Ser 147:197-217

Nejstgaard JC, Naustvoll LJ, Sazhin A (2001) Correcting for underestimation of microzooplankton grazing in bottle incubation experiments with mesozooplankton. Mar Ecol Prog Ser 221:59-75

Niehoff B (1996) Gonad development and egg production of three Calanus species (Copepoda): field observations, histology and experiments. Ber Polarforsch 213:1-157

Ohman MD, Runge JA (1994) Sustained fecundity when phytoplankton resources are in short supply: omnivory by Calanus finmarchicus in the Gulf of St. Lawrence. Limnol Oceanogr 39:21-36

Ohman MD, Snyder RA (1991) Growth-kinetics of the omnivorous oligotrich ciliate Strombidium sp. Limnol Oceanogr 36:922-935

Omori M, Ikeda T (1984) Methods in marine zooplankton ecology. John Wiley \& Sons, New York

Paasche E, Østergren I (1980) The annual cycle of plankton diatom growth and silica production in the inner Oslofjord. Limnol Oceanogr 25:481-494

Parrish KK, Wilson DF (1978) Fecundity studies on Acartia tonsa (Copepoda: Calanoida) in standardized culture. Mar Biol 46:65-81

Pond DW, Harris RP (1996) The lipid composition of the coccolithophore Emiliania huxleyi and its possible ecophysiological significance. J Mar Biol Assoc UK 76:579-594

Pond D, Harris R, Head R, Harbour D (1996) Environmental and nutritional factors determining seasonal variability in the fecundity and egg viability of Calanus helgolandicus in coastal waters off Plymouth, UK. Mar Ecol Prog Ser 143: $1-3$

Putt M, Stoecker DK (1989) An experimentally determined carbon:volume ratio for marine 'oligotrichous' ciliates from estuarine and coastal waters. Limnol Oceanogr 34: $1097-1103$

Richardson K, Jónasdóttir SH, Hay SJ, Christoffersen A (1999) Calanus finmarchicus egg production and food availability in the Faroe-Shetland Channel and northern North Sea: October-March. Fish Oceanogr 8:153-162

Roman MR (1984) Utilization of detritus by the copepod, Acartia tonsa. Limnol Oceanogr 29:949-959

Rousseau V, Mathot S, Lancelot C (1990) Calculating carbon 
biomass of Phaeocystis sp. from microscopic observations. Mar Biol 107:305-314

Schmidt K, Jónasdóttir SH (1997) Nutritional quality of two cyanobacteria: how rich is 'poor' food? Mar Ecol Prog Ser 151:1-3

Schmidt K, Kähler P, von Bodungen B (1998) Copepod egg production rates in the Pomeranian Bay (Southern Baltic Sea) as a function of phytoplankton abundance and taxonomic composition. Mar Ecol Prog Ser 174: 183-195

Shaw BA, Harrison PJ, Andersen RJ (1995) Feeding deterrence properties of apo-fucoxanthinoids from marine diatoms. II. Physiology of production of apo-fucoxanthinoids by the marine diatoms Phaeodactylum tricornutum and Thalassiosira pseudonana, and their feeding deterrent effects on the copepod Trigriopus californicus. Mar Biol 124:473-481

Smetacek V (1981) The annual cycle of protozooplankton in the Kiel Bight. Mar Biol 63:1-11

Editorial responsibility: Otto Kinne (Editor),

Oldendorf/Luhe, Germany
Stoecker DK, Capuzzo JM (1990) Predation on protozoa: its importance to zooplankton. J Plankton Res 12:891-908

Støttrup JG, Jensen J (1990) Influence of algal diet on feeding and egg production of the calanoid copepod Acartia tonsa Dana. J Exp Mar Biol Ecol 141:2-3

Svensen C, Egge JK, Stiansen JE (2001) Can silicate and turbulence regulate the vertical flux of biogenic matter? A mesocosm study. Mar Ecol Prog Ser 217:67-80

Welschmeyer NA (1994) Fluorometric analysis of chlorophyll $a$ in the presence of chlorophyll $b$ and pheopigments. Limnol Oceanogr 39:1985-1992

Wiborg KF (1954) Investigations on zooplankton in coastal and offshore waters of western and northwestern Norway with special reference to the copepods. Fiskeridir Skr Ser Havunders 11:1-246

Widdows J (1991) Physiological ecology of mussel larvae. Aquaculture 94:2-3

Zar JH (1996) Biostatistical analysis. Prentice Hall, Upper Saddle River, NJ

Submitted: July 24, 2000; Accepted: July 10, 2001

Proofs received from author(s): September 27, 2001 